\title{
Revisiting James Madison University: A Case Analysis of Program Restructuring Following So Called 'Title IX' Cuts
}

\author{
Ellen J. Staurowsky with Kevin Murray, \\ Matthew Puzio, and John Quagliariello \\ Drexel University
}

\begin{abstract}
The purpose of this study was to revisit one of the most highly publicized cases alleging Title IX harmed male athletes at James Madison University (JMU) following a decision that cuts would be made to the athletic program in 2006. Using budget data and publicly available information about the JMU athletic program, comparisons were made between the academic years 2006-2007 and 2010-2011. The authors conclude that the cuts in the JMU program were motivated far more by forces associated with the upward drift phenomenon in intercollegiate athletics, as evidenced in an institutional commitment to an expansion project costing $\$ 62$ million for the football stadium in 2009 than concerns about Title IX. As the analysis reveals, despite public concern that Title IX had harmed male athletes, the athletic department restructuring at JMU did not increase opportunities for female athletes, did not result in the disappearance of men's teams although those teams were demoted to club status, and did not inhibit the assumption of significant institutional debt to support the football program.
\end{abstract}

The summer of 2012 marked the 40th anniversary of the passage of Title IX of the Education Amendments Act of 1972, an act that bars sex discrimination in U.S. schools receiving federal financial support (Fagan \& Cyphers, 2012). During the past four decades, Title IX's impact in the area of school sport programs has been controversial and contested (McAndrews, 2012; Pemberton, 2012; Walton $\&$ Helstein, 2008). While Title IX has been credited with fostering unprecedented growth in opportunities for female athletes, it has also been blamed for harming the prospects for male athletes through program cuts (Glover, 2011; Langton, 2009). Despite the work of scholars and Title IX activists to demonstrate that cuts in men's programs are often wrongly attributed to Title IX, a perception that gains in women's sport have come at the expense of men endures (Cheslock, 2007, 2008; Staurowsky, 2011).

This palpable sense that Title IX has promoted an injustice against men is stirred each time school officials eliminate men's sport and invoke Title IX requirements as a cause for those decisions. At the college and university level, the cases have become symbols of federal government intrusion into the educational system that

The authors are with the Department of Sport Management, Drexel University, Philadelphia, PA 
has produced the "unintended consequence" of limiting opportunities for male students through the application of an "illegal" quota system (Ridpath, Yiamouyiannis, Lawrence \& Galles, 2008; Samuels \& Galles, 2003).

Since the 1990s, court cases filed by male athlete plaintiffs alleging harms done as a result of Title IX's application to athletic departments have all failed. Nine federal courts have determined that Title IX's enforcement scheme is not a quota system (National Women's Law Center, 2011). As a matter of individual institutional autonomy, schools may exercise the right to determine how funding is going to be allocated and in what areas as long as those allocations are done in a gender equitable fashion (National Women's Law Center, 2012).

Despite the controversy that occurs in the immediate aftermath of a college and university announcing program cuts (Lukas, 2012), very little attention is paid to what happens within an athletic department after cuts are made. The purpose of this study was to revisit one of the most highly publicized cases alleging Title IX harmed male athletes at James Madison University (JMU) following a decision that cuts would be made to the athletic program in 2006. This case was chosen because JMU officials represented the decision to cut programs as motivated by Title IX while selectively failing to disclose that during the same period, greater institutional resources were being devoted to the football program in preparation for playing in a more competitive conference (Lopiano, October 6, 2006; Staurowsky, 2006, 2007, 2011).

Using budget data and publicly available information about the JMU athletic program, this case study sought to address whether JMU achieved a Title IX compliant department five years after the cuts were made; the impact of the cuts have on male students at JMU; and any changes to JMU's athletics business model since the 2006 cuts? To create context for the James Madison case, the literature review provides a basic overview of the Title IX enforcement scheme along with a case history.

\section{The Basic Title IX Enforcement Scheme}

In the late 1960s, with momentum fueled by the Civil Rights and Women's Movements, Congressional leaders conducted hearings about the discrimination women were experiencing in educational institutions. The bill eventually emerging out of those investigations was Title IX, passed in 1972 as a component of omnibus legislation addressing education reform, which was signed into law by President Richard M. Nixon (Carpenter \& Acosta, 2004; Hogshead-Makar \& Zimbalist, 2007; Sack \& Staurowsky, 1997; Ware, 2011). In the years following its passage, the statute's application to athletic departments has been implemented by the Department of Education (and its predecessor, the Department of Health, Education and Welfare) through regulations, interpretations, letters of clarification, and court opinions (Bonnette, 2004; Carpenter \& Acosta, 2004; Hogshead-Makar \& Zimbalist, 2007).

Title IX's enforcement scheme is anchored in regulations promulgated in 1975 requiring educational institutions to offer female and male athletes equal access to athletic opportunities, access to athletically-related financial aid proportional to participation, and access to equitable benefits accorded athletes in operational areas that support performance and experience (Title IX regulation, 1975). ${ }^{1}$ Over the years, the menu of those operational areas has come to be known as the "laundry 
list," referring to items such as academic support, access to coaching and coach compensation, equipment, facilities and locker rooms, housing and meals, publicity, scheduling of games and practices, sports medicine support, travel, and support services. What this means in a practical sense is that Title IX calls for athletic departments to provide equal opportunity to female and male athletes. Once that opportunity has been extended, there is an expectation that athletes will be treated equitably. ${ }^{2}$

In an effort to provide the public with a means of gauging how well schools have met the requirements of Title IX, colleges and universities must complete and submit to the U.S. Department of Education an annual Equity in Athletics Disclosure Act report with information about the allocation of resources within their athletic programs. Under this obligation, schools account for the revenues and expenses for each sport offered in an athletic department by gender, as well as expenses associated with athletically related aid, coach salaries, and recruiting. There are considerable limitations, however, to the data reported in the EADA. As Buzuvis and Newhall (2012) note, the data are not detailed enough to judge whether institutions allocate financial resources in a way that meets the standards of equal treatment under Title IX. That said, the EADA database serves as an important resource in generally assessing Title IX progress and identifying potential problem areas.

\section{Assessing Equal Access to Athletic Opportunities: The Three-Part Test}

The Title IX Policy Interpretation (U. S. Department of Health, Education, \& Welfare, 1979) sets forth a three-part test as a means by which participation opportunities for females and males within athletic departments are assessed. Offering flexibility for schools to comply with its requirements in myriad ways based on available resources and institutional priorities, the Department of Education considers athletic department compliance on a case-by-case basis. As a result, a school needs to meet the standards of one of the three parts of the test to be deemed in compliance in the athletic participation area. Under the three part test, schools are asked

1. Whether intercollegiate level participation opportunities for male and female students are provided in numbers substantially proportionate to their respective enrollments; or

2. Whether the institution can show a history and continuing practice of program expansion which is demonstrably responsive to the developing interest and abilities of the members of that sex; or

3. Whether it can be demonstrated that the interests and abilities of the members of that sex have been fully and effectively accommodated by the present program.

The three part test is unique within civil rights enforcement schemes. Its distinguishing feature is the second part of the test, which offers "an exceptionally and atypically generous standard for measuring civil rights compliance" (Samuels $\&$ Galles, 2003, p. 15). What the second part of the test provides is an opportunity for a school that is otherwise out of compliance to satisfy Title IX requirements "if a school has an equity plan and regularly accounts for the growing interests and abilities of the underrepresented sex" (p. 15). 


\section{Assessing Substantial Proportionality in Athletic Participation Opportunities}

Determining who counts as an athlete and under what circumstances is important in assessing if athletic participation opportunities are substantially proportional to enrollment under the first part of the three-part. The 1979 Policy Interpretation defines athletes as individuals who:

(a) Are receiving the institutionally sponsored support normally provided to athletes competing at the institution involved (e.g., coaching, equipment, medical and training room services) on a regular basis during a sport's season; and

(b) Are participating in organized practice sessions and other team meetings and activities on a regular basis during a sport's season; and

(c) Are listed on the eligibility or squad lists maintained for each sport; and

(d) Because of injury, cannot meet a, b, or c above but continue to receive financial aid on the basis of athletic ability (U. S. Department of Health, Education, \& Welfare, 1979, n.p.).

Because athletes may compete on more than one athletic team, the athlete count for participation opportunities is referred to as a "duplicated" count. In evaluating whether participation opportunities are offered substantially proportionate to enrollment, the ratio of opportunities available to female athletes in the program is compared with the ratio of females in the student population. In turn, the ratio of opportunities available to male athletes in the program is compared with the ratio of males in the student population (Cantu, 1996).

Substantial proportionality is achieved when the gender ratios in the athletic department mirror those of students in the general student population. Importantly, the 1996 clarification issued by the Office for Civil Rights (OCR) focuses not on percentages per se but on what those percentages mean (Cantu, 1996). According to the National Women's Law Center (September 2011), “... a school will not be considered to have achieved 'substantial proportionality' if the number of additional opportunities that would be required to achieve proportionality is sufficient to sustain a viable team" (p. 21). Thus, modest gaps in proportionality may turn out to be important shortfalls in participation opportunities. ${ }^{3}$

\section{Title IX and the Strategy of Roster Management}

While substantial proportionality in participation opportunities provides a basis for the start of a Title IX analysis, it is merely that, a starting point. Clarification letters issued by the Office for Civil Rights reiterate the three-part test's possibilities in affording schools latitude in terms of compliance (Ali, 2010; Cantu, 1996; Reynolds, 2003). While these clarifications make it clear institutions may opt to reduce opportunities of the over-represented sex to achieve compliance, "...there is nothing in Title IX that requires the cutting or reduction of teams in order to demonstrate compliance with Title IX, and...the elimination of teams is a disfavored practice" (Reynolds, 2003, n.p.). In the late 1990s, as college and university officials explored 
avenues to comply with Title IX, a practice known as roster management emerged. The theory behind the practice was fairly straightforward. ${ }^{4}$

In athletic departments that fell short of meeting Title IX requirements, administrators implemented a policy that capped or limited the number of male athletes listed on team rosters while padding or inflating the number of female athletes listed on team rosters (Steinbach, 2000). Over time, a strategy designed to increase opportunities for female athletes while not adding women's teams led to several abuses. One was the creation of "ghost participation slots," meaning school officials were reporting hypothetical squad sizes that exceeded the actual number of women competing on teams (Lopiano, 2011). For example, administrators would claim there were 18 women on a softball team based on the slots available, even though there were only 15 players on the team. When discovered, this practice was found to be unacceptable under Title IX. As Lopiano (2011) explained, "Courts ruled that counted athletic participation opportunities must reflect actual opportunities filled by actual students .... and could not be 'ghost slots' or opportunities that a school claims that it offers but that are not filled by students" (n.p.).

Roster management was at issue in a lawsuit filed against Quinnipiac University when questionable accounting methods suggesting a conscious effort to fraudulently misrepresent the number of participation opportunities for women were revealed (Biediger v. Quinnipiac, 2009; 2010, 2012). Female cross country runners were required to participate on the indoor and outdoor track teams so they could be counted three times in the proportionality calculation. The court determined the "principal role" of those athletes was "to provide a gender statistic rather than a meaningful contribution to the team" resulting in a ratio of female athlete participation compared with the general female student population that was illusory (Biediger v. Quinnipiac, 2009, p. 35). In August of 2012, the U.S. Court of Appeals for the Second Circuit affirmed the district court's ruling that Qunnipiac discriminated against female athletes on their campus (Biediger v. Quinnipiac, 2012).

A New York Times investigation into roster management practices revealed that schools engage in a variety of strategies that result in proportionality ratios appearing better than what they are in reality (Thomas, 2011). Detecting that something might not be quite right with the numbers, Thomas found some institutions were counting male practice players as female athletes; female athletes were being required to compete on multiple teams; and some female athletes listed on team rosters were not members of those teams. Identifying the importance of pursuing "red flags" that signal potential Title IX violations, Lopiano (2011) wrote,

If there are not legitimate reasons for such large numbers or if those large numbers persist over many years and many teams, it is apparent that the school is manipulating its women's participation numbers to feign Prong One compliance without actually providing genuine athletic participation opportunities to them (n.p.).

\section{Assessing Equitable Allocation of Athletic Scholarships and Equitable Treatment}

According to the Title IX Interpretation on Intercollegiate Athletics (1979), the awarding of athletically-related financial aid generally meets the standard of com- 
pliance when allocations are proportional to the representation of female and male athletes in the program. Thus, if 53\% of athletes in the program are female, there is an expectation that $53 \%$ of athletic scholarship funding is allocated to female athletes. Due to limitations on athletic scholarships, athletes may receive what amounts to only one full athletic scholarship. Thus, even if she or he competes in more than one sport, the scholarship allocation will not exceed an amount that includes compensation for tuition, room and board, and books.

\section{James Madison University's "Title IX Cuts": An Abbreviated Case History}

On a fall Friday afternoon in late September of 2006, officials at James Madison University announced a plan to eliminate seven men's teams (archery, cross country, gymnastics, indoor and outdoor track, swimming, and wrestling) and three women's teams (archery, fencing, and gymnastics) by the next academic year (King, 2006; JMU Enacts, 2006). The JMU Board of Visitors cited challenges associated with Title IX compliance as the reason for eliminating nearly one-third of its entire athletic program, claiming that the plan adopted was "our most viable alternative" (JMU enacts... ). The plan to comply with Title IX hinged on achieving compliance under the first part of the three-part test, that being substantial proportionality. In explaining the decision, associate vice president of communications Andy Perrine elaborated, "We would not have done it [cut teams] if not for Title IX. There was just about no way we could add more women's programs and afford it and be in compliance" (Redden, 2006).

Immediately after the announcement, some of the affected athletes and their allies mobilized on campus to voice their opposition (Goldenbach, 2006; Lemke, 2006; McCarthy, 2006; Pennington, 2006, 2007). Public demonstrations gave way to the formation of a not-for-profit group called Equity in Athletics, Inc. (EIA), a coalition of athletes, alumni, boosters, coaches and parents, intent on fighting the decision. Supported in their efforts by what was then called the College Sports Council, since renamed the American Sports Council, EIA sought a preliminary injunction to stop the cutting of men's sports and alleging the enforcement scheme of Title IX had a disparate impact on male athletes (EIA, Inc. v. Department of Education, 2007). The lawsuit challenged JMU's decision to rely on the three-part test, which EIA argued was constitutionally and procedurally invalid. However, the district court rejected the merits of these claims and dismissed the case, and EIA's subsequent appeals failed to change this outcome (EIA, Inc, 2009; EIA, Inc., 2011: Sander, 2011, Toporek, 2012).

While EIA accepted the JMU assertions on face value, Title IX experts noted several factual issues in the case that raised questions about just how much of the motivation behind the program cuts at JMU were attributable to Title IX (Lopiano, October 11, 2006; Staurowsky, 2006). Based on the record, the institution did have challenges with Title IX compliance in the athletic department. ${ }^{5}$ According to the press release issued by JMU on September 29, 2006,

The proportionality requirements of Title IX mandate that collegiate athletics programs mirror each school's undergraduate population in terms of gender. 
As of the fall semester 2006, JMU's proportions place it fundamentally out of compliance with federal law.

The analysis offered by JMU was true in part, but the interpretation was extremely narrow and factually misleading in its representation of what Title IX requires. This nuance is evident when considered in light of the Title IX enforcement scheme, which provides a three-part test for schools to consider when evaluating access to participation opportunities. The three-part test serves as a guide to ask three questions:

RQ1: Had JMU offered athletic opportunities to men and women substantially proportional to their representation within the student body?

RQ2: Had JMU established a history and continuing practice of expanding programs for the underrepresented sex?

RQ3: Had JMU accommodated the interests and abilities of athletes of the underrepresented sex?

Notably, an institution may achieve compliance by satisfying one part of the three part test. Thus, even though JMU did not satisfy the proportionality standard in the three-part test, with $51 \%$ of students on campus being women while only $39 \%$ of athletes were women, alternatives were available to address Title IX concerns. Specifically the institution could have offered more sports for women. In addition, the cutting of women's programs as part of the plan to achieve compliance exacerbated the problem by violating the second and third part of the test. An institution can neither argue it has a history and continuing practice of program expansion nor it is fully accommodating the interests and abilities of female athletes after cutting existing programs (Cantu, 1996; Carpenter \& Acosta, 2004).

According to JMU officials, alternatives under Title IX to expand the women's program rather than cut teams were not viable because of the debt that would have accompanied those additions (King, 2006). Significantly, the institution's tolerance for the assumption of debt for the athletic department varied depending on the sport (Staurowsky, 2006, 2007, 2011). For example, EADA data for 2006-2007 revealed the football program carried an $\$ 800,000$ deficit that year. Comparing deficits for the 2004-2005 fiscal year based on NCAA reports, a football deficit in excess of $\$ 250,000$ was larger than the combined deficit for all other men's and women's nonrevenue teams combined (Alesia, 2006). Further, a new athletics performance center with locker rooms and office space for the football team was in the process of being completed, requiring $\$ 2.8$ million to be drawn from institutional reserves and other nontax sources ("JMU to break ground", 2003).

While JMU's decision to cut programs had the potential to respond to some of Title IX's requirements, football's strategic absence from the rationale prevented an understanding the athletic department was repositioning to respond to a more competitive environment (Staurowsky, 2006, 2007, 2011). The announcement of the JMU athletic cuts coincided with the institution's move to the Colonial Athletic Conference (CAA), a conference where the level of competition in the sport of football was going to demand an even greater financial commitment to the football program to remain competitive (Staurowsky, 2011). With limited resources, the JMU athletic department was already experiencing the strain of operating a 
competitive football program in what was then called the NCAA Division I-AA. At the time, JMU was dedicating six percent more of its resources to football and five percent less to other men's nonrevenue sports compared with other NCAA Division I-AA programs in 2006-2007 (Staurowsky, 2011). ${ }^{6}$ As athletic director Jeff Bourne conceded, “...the broad elimination of teams was necessary for the future management of the athletics program" (Lipka, 2006).

\section{Method}

In an effort to assess how JMU's athletic program changed financially and in terms of athletic participation five years after the announcement of program cuts in 2006, three primary information sources were consulted. First, budgetary information for the JMU athletic department for the academic years 2006-2007 and 2010-2011 was obtained through the Equity in Athletics Disclosure Act (EADA) reports filed by James Madison University with the U.S. Department of Education. Second, reports completed by the Auditor of Public Accounts for the Commonwealth of Virginia in the form of annual audits of JMU's intercollegiate athletics programs for a six year span, from 2005 to 2006 through 2010-2011, also provided a good source for budget information and financial activity. Third, news stories as well as the JMU website provided additional sources of material to support the analysis. As information was found and organized, the authors also consulted with three leading experts in the area of college sport and Title IX to test the interpretation of the findings. ${ }^{7}$

\section{Results \& Discussion}

\section{Question 1. Has JMU Established A Sustainable Title IX Compliant Athletic Department?}

Participation Opportunities and Number of Athletes. In the aftermath of the cuts made to the JMU athletic department in the name of Title IX, it seems reasonable to ask if those cuts resulted in a Title IX compliant athletic department. An analysis of data reveals a mixed-picture with regard to Title IX compliance. On the surface, percentages suggest progress has been made. As shown in Table 1, the proportionality gap, which favored male athletes by $10 \%$ in 2006-2007 shrunk to $4 \%$ in $2010-2011 .{ }^{8}$ The improvement by itself may not be sufficient to defend against a Title IX claim challenging JMU for failing to meet the proportionality standard. JMU negated the possibility of meeting the requirements of the three-part test by neither demonstrating a history and continuing practice of program expansion nor fully accommodating the interests and abilities of female athletes on their campus by eliminating existing women's programs. The $4 \%$ gap in participation represents the absence of opportunities for 24 female athletes, a number that would support the addition of at least one more women's team.

Beyond the surface percentages themselves, there is also the matter of the loss of opportunities for both male and female athletes. There were 85 fewer playing opportunities available for men and 31 fewer playing opportunities available for women in 2010-2011 than in 2006 (see Table 2). In terms of actual number of 
Table 1 Proportion of Female \& Male Athletes in JMU Program Compared with Student Enrollment 2006-2007 \& 2010-2011

\begin{tabular}{lccc}
\hline 2006-2007 & 2006-2007 & $\begin{array}{c}\text { Proportionality Gap } \\
\text { (Student Enrollment } \\
\text { Percentage-Athlete } \\
\text { Percentage) }\end{array}$ \\
\hline Male & $6,535 / 16,970=39 \%$ & $346 / 713=49 \%$ & $+10 \%$ \\
Female & $10,435 / 16,970=61 \%$ & $367 / 713=51 \%$ & $-10 \%$ \\
\hline & $\mathbf{2 0 1 0 - 2 0 1 1}$ & $\mathbf{2 0 1 0 - 2 0 1 1}$ & Proportionality Gap \\
\hline Male & Student Enrollment & Athlete & $+4 \%$ \\
Female & $10,734 / 16,803=40 \%$ & $261 / 597=44 \%$ & $-4 \%$ \\
\hline
\end{tabular}

Note: Substantial proportionality is calculated by comparing the percent of males and females in the student population with the percent of males and females in the athlete population.

Table 2 Number of JMU Male \& Female Participation Opportunities 2006-2007 \& 2010-2011

\begin{tabular}{lccc}
\hline & 2006-2007 & $\mathbf{2 0 1 0 - 2 0 1 1}$ & $\begin{array}{c}\text { Decline in } \\
\text { Number of JMU } \\
\text { Participation } \\
\text { Opportunities }\end{array}$ \\
\hline Male Opportunities & 346 & 261 & -85 \\
Female Opportunities & 367 & 336 & -31 \\
\hline
\end{tabular}

athletes, the total number of male athletes within the JMU program dropped by 45 in the 5 years following the cuts, while the total number of female athletes dropped by 38 (see Table 3 ). ${ }^{9}$ Further, while the JMU men's program reported a decrease in the number of multisport athletes by 40 after the cuts, there was a reported increase of multisport athletes by nine among JMU women athletes.

To compound matters, the reliance on multisport athletes in the JMU women's program has historically been greater as reflected in Table 4. In 2006-2007, 11.8\% of the overall JMU men's program was comprised of multisport athletes compared with nearly twice that many in the women's program (22.3\%). After the cuts to the JMU program, the percent of multisport athletes in the men's program dropped to a negligible .3\%, while the percent of multisport athletes in the women's program rose to $26.48 \%$. The fact that well over a quarter of the female athlete population was comprised of multisport athletes represents a difference that warrants an explanation and may hint at potential manipulations in the roster management system that inflate the female participation numbers and suppress the number of male participants. There may be a defensible explanation under Title IX for this discrepancy. However, in light of recent attention to the issue of how female athletes are counted within athletic departments (Thomas, 2011; Lopiano, November 2006), the discrepancy 
Table 3 Number of JMU Male \& Female Athletes 2006-2007 \& 2010-2011

\begin{tabular}{lccc}
\hline & 2006-2007 & 2010-2011 & $\begin{array}{c}\text { Decline in Number } \\
\text { of JMU Athletes }\end{array}$ \\
\hline Male Athletes & 305 & 260 & -45 \\
Female Athletes & 285 & 247 & -38 \\
\hline
\end{tabular}

Table 4 Percent of Multi-Sport Athletes on JMU Men's and Women's Teams

\begin{tabular}{lccccc}
\hline & $\begin{array}{c}\text { Reporting } \\
\text { Year }\end{array}$ & $\begin{array}{c}\text { Unduplicated } \\
\text { Number }\end{array}$ & $\begin{array}{c}\text { Duplicated } \\
\text { Number }\end{array}$ & $\begin{array}{c}\text { Multi-Sport } \\
\text { Athletes }\end{array}$ & $\begin{array}{c}\text { Percent of } \\
\text { Program With } \\
\text { Multi-Sport } \\
\text { Athletes }\end{array}$ \\
\hline Men & & & & & \\
& $2006-2007$ & 346 & 305 & $346-305=41$ & $11.80 \%$ \\
Women & $2010-2011$ & 261 & 260 & $261-260=1$ & $.30 \%$ \\
& $2006-2007$ & 367 & 285 & $367-285=82$ & $22.30 \%$ \\
& $2010-2011$ & 336 & 247 & $336-247=39$ & $26.48 \%$ \\
\hline
\end{tabular}

Note: Unduplicated number refers to the number of opportunities available for athletes to participate. The EADA defines the unduplicated number as a head count of all participants on at least one varsity team, by gender. Duplicated number refers to the number of athletes in the program counted only once, regardless of the number of teams they participate on. Multisport athletes refer to the number of athletes who participate on two or more teams.

is an area of vulnerability that speaks to equal access. If more multisport female athletes are on athletic scholarship compared with their male counterparts, what is the nongender specific rationale to explain this difference? An argument might be made that female athletes in the JMU program have more demands placed on them to retain those scholarships if they are competing in more than one sport.

The reported roster sizes for JMU women's teams in 2010-2011 also present potential areas of questions in a Title IX review. ${ }^{10}$ The number of athletes listed for women's basketball is 23 . The average squad size for NCAA Division I women's basketball teams in 2010-2011 was 14.4 (Irick, 2011). This number seems out of balance with a program that provides reasonable opportunities for female athletes to receive coaching, playing time, and other services. It further raises the question if the excess number is due to male practice players being listed as part of the women's basketball team. ${ }^{11}$

Of the ten sports offered to female athletes at JMU, the number of female athletes reported to be carried on their rosters exceeds the average NCAA squad sizes in those sports, with the exception of golf. The variations range from less than one additional player in tennis to 17.8 above the average in all track and field 
combined. All told, the varsity sport offerings for women at JMU in twelve sports were reported to offer 336 athletic opportunities to female athletes in 2010-2011. Based on NCAA average squad sizes, the average Division I institution offering those sports had 270 female athletes participating (Irick, 2011).

In sum, based on the available EADA data, JMU's declaration to comply with Title IX using substantial proportionality was not realized five years after the cuts in the programs were made. The department also failed to achieve compliance under a history and continuing practice of program expansion or accommodating interests and abilities due to the cuts made to the women's teams. While further exploration regarding the counting of athletes in the program would need to be done to better understand the roster management strategy at work at JMU, data that is publicly available points to some areas of questions that would most likely be explored in a Title IX review.

Allocation of Athletic Scholarships. Since 2006-2007, reallocation of some resources into the JMU women's programs has been made based on EADA data. In the area of athletically-related financial aid, the amount awarded to female athletes in 2006-2007 fell one percentage point short of a proportional allocation based on their participation (48\% of athletic scholarship budget compared with $49 \%$ in the athletic population). In 2010-2011, female athletes received slightly more than their proportional share of athletic scholarships (53\% compared with their representation in the athletic program at 49\%). Female athletes on the JMU campus received more than $\$ 1.3$ million in athletic scholarship assistance in 2010-2011 than they did five years previously, a figure that far surpassed the $\$ 13,500$ in scholarship savings released at the time the cuts were made ("JMU enacts..."). In contrast, male athletes at JMU received an increase of approximately $\$ 850,000$ in additional athletic scholarship support (see Tables 5 and 6). ${ }^{12}$

To summarize, JMU female athletes received more in athletic scholarship assistance five years after the cuts occurred, with the allocation exceeding their representation in the athletic population by four percent. The scholarship savings realized at the time of the cuts, however, does not account for the nearly $\$ 2$ million increase in scholarship dollars infused into the athletic department since 2006 which benefitted both female and male athletes.

Table 5 Proportion of Duplicated Athletes in JMU Program 20062007 \& 2010-2011

\begin{tabular}{lcc}
\hline & $\begin{array}{c}\text { 2006-2007 } \\
\text { Athlete Population }\end{array}$ & Percent \\
\hline Male & $305 / 590$ & $52 \%$ \\
Female & $285 / 590$ & $48 \%$ \\
\hline & $\mathbf{2 0 1 0 - 2 0 1 1}$ & \\
\hline Male & Athlete Population & $51 \%$ \\
Female & $260 / 507$ & $49 \%$ \\
\hline
\end{tabular}


Allocation of Recruiting Dollars. The distribution of resources for recruiting purposes in 2010-2011 was almost proportional to participation opportunities, a circumstance similar to five years ago as shown in Table 7. Interestingly, this was achieved despite the fact that the men's total recruiting dollars were decreased by $\$ 2,444$ while the women's recruiting budget was increased by $\$ 44,082$. While the decrease in budget on the men's side makes sense to some degree given the number of men's teams cut, the fact that so little was taken away suggests either very little money had been devoted to supporting the recruitment of athletes in the men's teams that were eliminated or women's programs were underfunded relative to recruiting or perhaps a combination of both. The increase in the women's recruiting budget is a positive sign. However, given that substantial proportionality has not yet been achieved, the allocation made to support recruitment of women athletes potentially falls short of the support needed.

Number of Coaches and Compensation. In 2006-2007, there were 17 head coaches of men's teams at JMU, being paid on average $\$ 97,663$. The number of head coaches of women's teams that year was 13 . They, in turn, averaged $\$ 67,871$ per position. By 2010-2011, the number of head coaches of men's teams in the JMU athletic department had dropped to six while their average salary increased by $\$ 142,078$, an increase of $\$ 44,415$ per position. Head coaches of women's teams remained at 13 with an average salary of $\$ 82,203$ (see Table 8). While $56 \%$ of the overall allocation of salary dollars for head coaches was directed to women's programs, coaches of women's teams earned on average 36\% less than the head coaches of the men's teams. And despite the fact there were fewer male athletes in the program (261 male athletes compared with 336 female athletes), there was a larger number of assistant coaches devoted to male teams (see Table 9). As a result, more than $60 \%$ of assistant coach salaries was used to pay assistant

Table 6 Allocation of Athletically Related Financial Aid 2006-2007 \& 20102011

\begin{tabular}{lcccc}
\hline & $\begin{array}{c}\text { 2006-2007 } \\
\text { Amount }\end{array}$ & $\begin{array}{c}\text { 2006-2007 } \\
\text { Percent }\end{array}$ & $\begin{array}{c}\text { 2010-2011 } \\
\text { Amount }\end{array}$ & $\begin{array}{c}\text { 2010-2011 } \\
\text { Percent }\end{array}$ \\
\hline Men's Program & $\$ 2,049,693$ & $51 \%$ & $\$ 2,899,200$ & $47 \%$ \\
Women's Program & $\$ 1,951,880$ & $49 \%$ & $\$ 3,282,911$ & $53 \%$ \\
Total & $\$ 4,001,573$ & & $\$ 6,182,111$ & \\
\hline
\end{tabular}

Table 7 Allocation of Recruiting Expenses 2006-2007 \& 2010-2011

\begin{tabular}{lcccc}
\hline & $\begin{array}{c}\text { 2006-2007 } \\
\text { Amount }\end{array}$ & $\begin{array}{c}\text { 2006-2007 } \\
\text { Percent }\end{array}$ & $\begin{array}{c}\text { 2010-2011 } \\
\text { Amount }\end{array}$ & $\begin{array}{c}\text { 2010-2011 } \\
\text { Percent }\end{array}$ \\
\hline Men's Program & $\$ 134,990$ & $53 \%$ & $\$ 132,546$ & $44.5 \%$ \\
Women's Program & $\$ 121,285$ & $47 \%$ & $\$ 165,367$ & $55.5 \%$ \\
Total & $\$ 256,275$ & & $\$ 297,913$ & \\
\hline
\end{tabular}


Table 8 Comparison of JMU Number of Head Coaches \& Salaries 2006$2007 \&$ 2010-2011

\begin{tabular}{lccccc}
\hline & $\begin{array}{c}\text { Number } \\
\text { of Head } \\
\text { Coaches }\end{array}$ & $\begin{array}{c}\text { 2006-2007 } \\
\text { Average } \\
\text { Salary }\end{array}$ & $\begin{array}{c}\text { Number } \\
\text { of Head } \\
\text { Coaches }\end{array}$ & $\begin{array}{c}\text { 2010-2011 } \\
\text { Average } \\
\text { Salary }\end{array}$ & $\begin{array}{c}\text { Difference in } \\
\text { Increase }\end{array}$ \\
\hline Men's Program & 11 & $\$ 97,663$ & 6 & $\$ 142,078$ & $\$ 44,415$ \\
Women's Program & 13 & $\$ 67,871$ & 13 & $\$ 82,203$ & $\$ 14,332$ \\
\hline
\end{tabular}

Table 9 Comparison of JMU Number of Assistant Coaches \& Salaries 2006-2007 \& 2010-2011

\begin{tabular}{lccccc}
\hline & $\begin{array}{c}\text { Number of } \\
\text { Assistant } \\
\text { Coaches }\end{array}$ & $\begin{array}{c}\text { 2006-2007 } \\
\text { Average } \\
\text { Salary }\end{array}$ & $\begin{array}{c}\text { Number of } \\
\text { Assistant } \\
\text { Coaches }\end{array}$ & $\begin{array}{c}\text { 2010-2011 } \\
\text { Average } \\
\text { Salary }\end{array}$ & $\begin{array}{c}\text { Difference in } \\
\text { Increase }\end{array}$ \\
\hline Men's Program & 22 & $\$ 52,038$ & 18 & $\$ 57,112$ & $\$ 5,074$ \\
Women's Program & 19 & $\$ 37,972$ & 15 & $\$ 42,604$ & $\$ 4,632$ \\
\hline
\end{tabular}

coaches of men's teams. While discrepancies in compensation between coaches of men's and women's teams may not reflect gender discrimination, that coaches of men's teams appear to routinely earn more than coaches of women's teams raise a question that should be explored. ${ }^{13}$

\section{Question 2. What Impact Did the Cuts Have on Men at JMU?}

When college and university officials announce that men's programs are cut from athletic departments because of Title IX, there is a perception that men no longer play those sports on those campuses. A sample of headlines that emphasize the terminal nature of this impression include "Title IX A Losing Game for Men" from The National Review (Lukas, 2012), "Stop the Bleeding: Title IX and the Disappearance of Men's Intercollegiate Teams" from the Vanderbilt Journal of Entertainment and Technology Law (Langton, 2009), and "Title IX Creates Opportunities While Taking Many Away" in Coach and Athletic Director (Hoffman, 2012). The permanence of this cause and effect relationship between Title IX and the cutting of men's sports creates the impression male athletes disappeared and no longer play those sports on the JMU campus. And while the EADA data confirms that 45 fewer male athletes are competing in varsity sports, the sports themselves remain at JMU reconstituted in club form. As a consequence, male athletes did not actually disappear from campus. Nor did the institution intend for that to happen.

In a document entitled "Title IX Statement" issued by JMU in February of 2007, officials had given thought to the affected men's varsity teams becoming club sports. Specific to that point, they noted:

While some student-athletes may choose to transfer to another institution, those students who are interested will have the opportunity to continue their athletic endeavors at the club level. In some cases, clubs already exist that are 
associated with a particular sport. In other cases, we encourage the creation of such a club. The Athletic Department has recommended that the university provide funding to the associated clubs over the next three years to facilitate the transition to club status ("JMU Title IX statement", n.p.).

The presentation of this fact is not intended to diminish the disappointment athletes experience when their programs have been demoted from varsity to club status. At the same time, it is intended to clarify that opportunities to participate continue to exist with less institutional support but the capacity to still compete at the national level. For example, in the sport of archery, the men's and women's teams won both gold and silver medals at the Eastern Regional Intercollegiate Archery Championships in April of 2012 (MacDonald, 2012). Following the cuts in 2006, the athletic department funded the team through 2007.

In an interview with the JMU school newspaper, The Breeze, one of the last members of the team to remember being varsity, Ciera Abbate commented about the financial support received from the institution in 2012. She said:

We just have to do community service and get money through UREC and do fundraising for our own. But still we are able to get a lot. Everybody pays dues at the beginning of the year, and it's not unrealistic dues at all. It pays for our entry fees for tournaments and a lot of equipment" (MacDonald, n.p.).

The club also receives $\$ 6,000$ in funding from a foundation set up to honor of a former member of the team. In May of 2012, JMU hosted the U. S. Intercollegiate Archery Championships (MacDonald, n.p.).

On a campus with an award winning recreation and club sports division, the teams affected by demotion were not cast adrift but continued to receive administrative support, resources, and facilities. In 2009, JMU initiated the renovation of an area called University Park, an 85 acre field complex designed to support varsity sports, club teams, and campus recreation. ${ }^{14}$

To conclude, JMU did not eliminate men's sport opportunities, provided support to assist in facilitating a transition to club sport status for those teams, and created a mechanism to ensure male athletes continued to play at JMU if they so desired. ${ }^{15}$

\section{Question 3. How Has the Business Model for JMU Athletics Changed Since the 2006 Cuts?}

Based on the 2010-2011 EADA data, the \$550,000 savings from the 2006 cuts were absorbed into the athletics department budget and reallocated. Increases in team budgets for both men's and women's programs reflect overall growth well in excess of those savings. Team budgets in the men's programs realized an increase of $\$ 2,396,240$ while women's team budgets went up by $\$ 2,572,911$. Expenditures evidence similar patterns.

Due to the lack of specificity and detail in the EADA reporting mechanism, it is not possible to discern with confidence whether the overall athletic program is breaking even, profitable, or operating at a deficit. There are several reasons for this. According to the 2010-2011 EADA report, both the overall men's and women's programs appear to have made more in revenue than what was expended. However, in the budget category listed as "not allocated by gender" there is a $\$ 34,847$ shortfall, a shortfall that matches identically the $\$ 34,847$ "profit" reported for the men's and 
women's teams. It is difficult to reconcile those budget lines and whether there is something there to be examined further.

Second, the issue of the term "revenue" also requires further consideration. "Revenue" within the context of an EADA report merely refers to the budget available for an athletic department in any given reporting year. The U. S. Department of Education defines revenue for the purposes of the EADA as

"All revenues attributable to intercollegiate athletic activities. This includes
revenues from appearance guarantees and options, contributions from alumni
and others, institutional royalties, signage and other sponsorships, sport camps,
state or other government support, student activity fees, ticket and luxury box
sales, and any other revenues attributable to intercollegiate athletic activities"
(Equity in Athletics, 2012). ${ }^{16}$

While the EADA recognizes the various revenue streams that may contribute to an athletic budget, the report itself does not offer insight into where the money comes from to run athletics programs. According to state audit reports for the JMU intercollegiate athletic department, the primary revenue stream for its athletic department budget is a mandated student fee that pays for over $80 \%$ of JMU athletes (James Madison University intercollegiate athletics. . . , 2005; 2006; 2007; 2008; 2009; 2010; 2011). In 2006-2007, the athletic department relied on student fees for $86.2 \%$ of its budget. By 2010-2011, the overall contribution from student fees had been reduced to $83 \% .{ }^{17}$ Five years after the cuts to the athletic department were made, the amount of money contributed by student fees to the athletic department budget, which was $\$ 25,704,568$ in 2010-2011, surpassed the entire 2006-2007 athletic budget. An understanding of this language is important in assessing the true nature of the JMU athletic department and who it serves. As Table 10 demonstrates, this particular athletic department was heavily subsidized by students before the program cuts were made to the athletic department. It continues in the aftermath of those cuts to be heavily subsidized by students.

\section{Table 10 JMU Percent of Athletic Budget Subsidized by Student Fees 2004-2005 Through 2010-2011}

\begin{tabular}{lccc}
\hline & Student Fee Revenue & Total Revenue & Percent \\
\hline 2004-2005 (precut) & $\$ 17,818,323$ & $\$ 21,555,198$ & $86.2 \%$ \\
$2006-2007$ (precut) & $\$ 19,726,147$ & $\$ 22,953,986$ & $85.9 \%$ \\
$2006-2007$ & $\$ 21,264,599$ & $\$ 24,652,704$ & $\$ 86.2 \%$ \\
(year cut announced) & & & \\
$2007-2008$ (postcuts) & $\$ 22,158,879$ & $\$ 26,113,489$ & $84.8 \%$ \\
$2008-2009$ & $\$ 24,647,379$ & $\$ 29,817,059$ & $82.6 \%$ \\
$2009-2010$ & $\$ 23,992,226$ & $\$ 28,636,487$ & $83.7 \%$ \\
$2010-2011$ & $\$ 25,704,568$ & $\$ 30,957,078$ & $83.0 \%$ \\
\hline
\end{tabular}

Data drawn from the James Madison University Intercollegiate Athletic Audit conducted by the Auditor of Public Accounts, Commonwealth of Virginia for the years shown. 
JMU's institutional investment in athletic infrastructure at the time of the cuts and in the years to follow offers considerable credence to the theory that the actions taken by school administrators had little in actuality to do with Title IX and far more to do with an institutional desire to compete at a very high level in a number of sports, most particularly football. Several facts bear this out. First, according to EADA information for 2010-2011, the roster for the football team grew by forty players, from 102 to 142 . JMU was carrying a football squad that had 32 more players than the average NCAA Division I football program that year. Second, while increases occurred across the board in all team budget areas after the cuts, 74\% of all money allocated to operate men's athletic programs at JMU continued to be spent on just two sports: football and men's basketball. Third, at the time the cuts were made, the institution was in the midst of raising money for a $\$ 10$ million project that expanded locker rooms and office space for the football staff in the Plecker Athletic Performance Center. Within three years (in 2009), a campaign was launched to renovate the football stadium, an expansion whose total project cost was estimated at $\$ 62.5$ million, a project completed in $2011 .{ }^{18} \mathrm{~A}$ baseball and softball complex, estimated to have cost $\$ 8$ million, was also built during that period of time. The long-term debt associated with the football project is not expected to be settled until the year 2030. Out of roughly $\$ 100$ million in athletic and recreation facility construction that was ongoing or undertaken within a short period of time after program cuts occurred, approximately $80 \%$ was allocated to support the football program (James Madison University athletic complex and stadium, 2012; JMU Dukes Capital Projects, June 17, 2007).

\section{Conclusions}

On September 29, 2006, JMU officials issued a press release indicating "Once this plan [to cut ten teams] is fully implemented, total participation in athletics will move to 61 percent female and 39 percent male, in alignment with student enrollment." Five years after the cuts were made, that goal was not achieved, at least not according to the publicly available information reported by the institution through the EADA. In the meantime, fewer men were competing at the varsity level on the JMU campus but fewer women were competing, as well. What was achieved, however, was an expansion of the athletic complex that included a noticeable commitment to the football program.

While those male athletes whose teams were cut sought relief in the courts because of Title IX, and some members of the general public might have been persuaded that Title IX was responsible for making those male athletes disappear from the JMU campus, the forces that produced these cuts were at best tangentially related to Title IX. When viewed as an example of upward drift within athletic departments (Sperber, 2000; Weaver, 2010), where schools with limited resources attempt to chase the dream of big-time football, the decisions at JMU suggest that the institution made a calculated gamble in terms of whether a highly competitive football team will deliver a measure of public exposure and return on investment that makes all of this worthwhile. ${ }^{19}$

The expansion of the athletic complex speaks to the presence of the arms race in intercollegiate athletics, where the philosophy of "it takes money to make money" has been used to justify putting more and more resources into football and men's 
basketball (Weiner, 2009). In JMU's annual report for the fiscal year 2011-2012, fundraising efforts for the expansion of Bridgeforth Stadium were rationalized on the basis of a need

"...to address a shortage of seating as well as provide a next level of customer service to JMU fans and supporters. In addition, this expansion will serve as a recruiting advantage for JMU Football. The expanded stadium will also serve to increase donor and alumni involvement and financial contributions" (King, 2012, p. 29).

An express objective to maximize athletic revenues is expected to occur through ticket sales and marketing. "By providing a top level game day experience in conjunction with a well planned marketing effort, Athletics will realize revenues in excess of budgets and participants (fans, students \& athletes) will garner memorable JMU experiences" (King, p. 30). Following a familiar pattern, JMU opted to put money into those revenue-producers while cutting Olympic sports (HogsheadMakar, 2012; Cooper \& Weight, 2011).

Rather than a lesson in the unreasonable influence of Title IX within athletic departments, this case offers insight into the competing forces of commercial and educational interests that have been playing out within college and university athletic departments in the four decades since Title IX was passed (Hogshead-Makar, 2012; Staurowsky, 2007). James Madison surveyed the landscape and decided strategically to commercialize their athletic programs for reasons specific to that institution. And those decisions are yielding additional prestige and revenue. In 2010-2011, JMU teams achieved a school record five CAA Conference Championships ("JMU athletics leading the way...", 2011). During the 2010 fall season, the football team became only the second FCS school to defeat a ranked FBS squad (then ranked \#13 Virginia Tech) in a regular season game ("JMU athletics leading the way..."). With the opening of the newly renovated Bridgeforth Stadium in the fall of 2011, JMU was second among NCAA Football Championship Series (FCS) schools in attendance that season (NCAA Accumulated Attendance Report, 2012).

In the fall of 2012, JMU played West Virginia, ranked eighth in the FBS in the preseason, at FedEx Field in Landover, Maryland (Schlabach, 2012). West Virginia earned a guarantee of $\$ 2.3$ million. JMU's projected share was a minimum of $\$ 350,000$ (Dunleavy, 2012), an amount that surpassed their entire football budget of $\$ 201,263$ in 2001 (Fairbank, 2011). ${ }^{20}$ And while a payday of that kind is evidence that JMU has positioned itself to make money off of its football program, it remains to be seen if the effort will result in the program paying for itself. As noted earlier, the entire athletic program, including football, continues to be subsidized heavily with student fees.

Further, to sustain the business that is now JMU athletics, the number of employees within the athletic department has grown and their roles and functions have expanded to match the demands of the enterprise. As a consequence, coaches are no longer the largest number of employees in this or many other athletic departments. For the 2010-2011 academic year, JMU has a professional staff of 80 working in a range of offices and areas including athletics administration (5), the business office (4), compliance (3), development (8), equipment management (5), facilities (9), human resources (1), marketing (6), athletics communications (8), sports medicine (11), sport psychology (2), strength and conditioning (7), 
student-athlete services (8), and tickets and customer relations (3) supported by a staff of 18 executive assistants, administrative assistants, and office managers (JMU Staff Directory, 2012-2013). In contrast, there are 54 head and assistant coaches.

Title IX is silent on the issue of how an institution runs its athletics programs. Its influence speaks only to the matter of equitable treatment and equal opportunity within whatever type of athletic program an institution wishes to offer. Five years after cuts to varsity programs at JMU were announced, it is clear that an institutional decision had been made to restructure the athletic department with the goal of promoting programs that had the potential to be highly visible and could attract commercial interest. At the same time, it left behind an athletic program that had valued a participatory model that accommodated a larger number of students. Electing to demote those teams to club status, JMU did not eliminate male athletes who compete in certain sports from their campus entirely but offered them an alternative. JMU's commitment to Title IX compliance remains somewhat in question given publicly available information.

One of the points of curiosity in this case is why the affected athletes did not have more leverage to reverse the decision given the JMU athletic department's reliance on student fee subsidies. According to a study done by USA Today analyzing the percent of tuition during 2010-2011 that went to athletic departments, JMU ranked fourth among 108 NCAA Division I institutions with $14.2 \%$ of every tuition dollar going to athletics (Berkowitz \& McCarthy, 2010). In real dollars, JMU placed fifth, with the fee per student based on in-state full time tuition being $\$ 1,114$ (Berkowitz \& McCarthy). ${ }^{21}$

The implications of gaining a more refined view of what happened at JMU lie in understanding the limits of what Title IX requires and the latitude that schools have to choose their athletic destinies in keeping with their own established priorities. In addition, such an understanding might also reveal why seeking redress under Title IX would not have yielded relief for the affected male athletes.

\section{Notes}

1. Section 106.3c addresses the provision of athletic scholarships. Section 106.41c addresses equal opportunity.

2. Under Title IX schools are not required to offer the same number of sports or even provide identical treatment to female and male athletes. Treatment must be consistent with standards appropriate to the nature of the sport and the caliber of treatment established by the institution. If men's teams receive top of the line equipment, then women's teams should receive top of the line equipment (Bonnette; Carpenter \& Acosta).

3. Substantial proportionality is not the same as exact proportionality. "Although it could be argued that there should be no difference between the percentages of athletes who are male/female and the percentages of enrolled students who are male/female, OCR recognizes that such exact proportionality would not always be a reasonable requirement" (National Women's Law Center, September 2011, p. 21). The substantial proportionality standard recognizes the natural ebb and flow in student enrollments that occur on a college or university campus.

4. According to Judge \& O'Brien (2012), "Today, roster management most often refers to setting caps on the number of young men who can participate in each varsity sport. In some institutions, roster management may also set minimum numbers for each varsity team in the women's program" (p. 145). 
5. In an unsigned editorial in the JMU school newspaper, The Breeze, in January of 2010 an interview with athletic director Jeff Bourne revealed that an unnamed club sport team asked to be elevated to varsity status in 2006. The club apparently challenged JMU on the grounds that it was not in compliance with Title IX. It is unclear from the report if this was a formal claim through the U.S. Department of Education Office for Civil Rights, a threatened lawsuit, or an internal student complaint. The editorial notes, "To avoid losing all federal funding, the school decided to comply with Title IX by eliminating 10 varsity teams". As a matter of factual record, while the potential for such a penalty does exist, no school in the United States has ever had their federal funding taken away as a result of noncompliance with Title IX.

6. James Madison University was, at one time, an all-women's institution. Athletics for women started in the 1920s. According to a JMU history of the athletics program, "Men's athletics began at JMU during the late 1940s, and a comprehensive program for men began evolving in the late 1960s when the university became fully coeducational" ("JMU athletics...", 2007). The decade of the 1970s and 1980s solidified the position of men's sports on the campus, a time that coincided with overall increasing student enrollments, and an ever-increasing percentage of female students (Staurowsky, 2011). At the time of the cuts, JMU's athletics program was tied for the rank of seventh among all NCAA Division I schools in 2006 in terms of the number of teams offered ("JMU enacts...", 2006; "Keep all 28...").

7. Experts were approached who had significant background in the legislative history of Title IX and its application to athletic departments. Two are lawyers (one with experience as an athletics administrator; one a Title IX litigator). Another was a scholar, consultant, and author.

8. The proportionality gap refers to the difference between the proportion of male/females in the student population compared with the proportion of male/female students in the athletic population.

9. The actual number of athletes in the program is different than the number of athletic participation opportunities because some athletes may compete on more than one team. EADA reporting uses "unduplicated" numbers to refer to the actual number of athletes; "duplicated" numbers to refer to participation opportunities. Multisport athletes are those athletes who compete on more than one team.

10. JMU reported larger squad sizes in men's sports compared with NCAA averages as well. Football and men's soccer were the most dramatic with the football roster carrying 142 compared with 109.6 on average among NCAA Division I football programs. JMU men's soccer had a reported squad size of 44; the NCAA average was. 28.5.

11. In JMU's 2007 statement about the decision to cut teams, it noted, "Teams must meet roster numbers to compete, and they cannot exceed scholarship numbers set by the NCAA" (n.p.). In NCAA Division I women's basketball, that limit is 15 .

12. It should be noted that while the increase in financial aid to female athletes may be a sign of more gender equitable decision making within the athletic department, it cannot be assumed that the differential is due to the allocation of more scholarships. If, for example, the women's program enrolls more athletes who are from out of state, the difference may be due to that financial reality and not necessarily to an increase in the number of scholarships awarded.

13. The U.S. Equal Employment Opportunity Commission (EEOC) published the Enforcement Guidance on Sex Discrimination in the Compensation of Sports Coaches in Educational Institutions in 1997.

14. Some of the athletic fields in this space were acquisitions from what had formerly been the Harrisonburg High School athletic complex.

15. While rarely acknowledged, Title IX also covers the club sport area. It would require a separate analysis to determine if club sport opportunities are being provided equitably at JMU.

16. This definition can be found in the glossary on the website. 
17. Some portion of the dip in the percent of the JMU budget accounted for through student fees appears to be made up through a practice of assessing students interested in getting priority seating at football and basketball games. Students have the opportunity to join the Student Duke Club for a $\$ 25$ membership fee. In 2009, it was reported that the club donated $\$ 50,000$ to athlete scholarship support through their Student Duke Club membership (JMU Student Handbook, 2012) (See Student Duke Club at http://www.jmu.edu/judicial/handbook/StudentLifeSDC.html)

18. Information regarding costs associated with JMU athletic capital projects was found at the website for the JMU Office of Public Affairs, Campus Construction for 2012. Additional information regarding debt service was found in the James Madison University Intercollegiate Athletics Programs Audit for the years 2005-2011. http://www.jmu.edu/news/campusConstruction.shtml

19. The concept of upward drift was introduced by Kerr (1991) to capture a shift in higher education where institutions were pursuing rankings in research and the attendant markers of research institutions (funding and prestige).

20. JMU lost in a lopsided game that favored West Virginia. The final score was 42-12 (Stubbs, 2012).

21. The question of whether the athletes affected by the program cuts could have demanded that their student fees be withheld or that the student body in general pass a resolution to stop financing the athletic department until the program was more representative of student wishes is complicated and would require another manuscript.

\section{Acknowledgments}

The authors wish to thank Kristen Galles, Jeff Orleans, and Dr. Bernice Sandler for sharing their insights about the history of Title IX and its application to athletic departments with us.

\section{References}

Alesia, M. (2006). NCAA financial reports database. Indianapolis Star. Retrieved from http://www2.indystar.com/NCAA_financial_reports/

Ali, R. (2010, April). Dear colleague letter: Office of the assistant secretary. Title IX and the three-part test. Washington, DC: United States Department of Education Office for Civil Rights. Retrieved from http://www2.ed.gov/about/offices/list/ocr/letters/ colleague-201010.html

Berkowitz, S., \& McCarthy, M. (2010, September 21). Analyzing the percentage of tuition that goes to athletics. USA Today. Retrieved from http://www.usatoday.com/sports/ college/2010-09-21-athletic-fees-chart_N.htm

Biediger v. Quinnipiac University, 616 F. Supp. 2d 277 (2009, U. S. District).

Biediger v. Quinnipiac University, 2010 U. S. Dist. Lexis 50044 (2010, U.S. District).

Biediger v. Qunnipiac University, 2012 U.S. App. Lexis 16398 (2012, U.S. ${ }^{\text {nd }}$ ).

Bonnette, V.M. (2004). Title IX and intercollegiate athletics: How it all works - in plain English. Self-published.

Buzuvis, E., \& Newhall, K.E. (2012). Equality beyond the three-part test: Exploring and explaining the invisibility of Title IX's equal treatment requirement. Marquette Sports Law Review, 22, 427-450.

Cantu, N. (1996, January 16). Dear colleague letter: Clarification of intercollegiate athletics policy guidance: The three-part test. Washington, DC: United States Department of Education Office for Civil Rights. Retrieved from http://www2.ed.gov/about/offices/ list/ocr/docs/clarific.html

Carpenter, L.J., \& Acosta, V. (2004). Title IX. Champaign, IL: Human Kinetics Publishers.

Cheslock, J. (2007). "Who is playing college sports?" Retrieved from http://www.womenssportsfoundation.org. 
Cheslock, J. (2008). Who's Playing College Sports? Money, Race, and Gender. East Meadow, NY: Women's Sports Foundation.

Cooper, C., \& Weight, E. (2011). An examination of administrators' nonrevenue, Olympic program values within NCAA athletic departments. Journal of Intercollegiate Sport, $4(2), 247-260$.

Dunleavy, K. (2012, July 20). West Virginia-JMU set for FedEx in 2012. The Examiner. http://washingtonexaminer.com/article/147600

Equity in Athletics Data Analysis Cutting Tool Website. (2012). Washington, DC: United States Department of Education. Retrieved from http://ope.ed.gov/athletics/

Equity in Athletics, Inc. v. Department of Education, 2007 U.S. Dist. LEXIS 61211 (2007,W.D. Va.).

Equity in Athletics, Inc. v. Dep't of Education, No. 5:07-0028-GEC (2009, W.D. Va.).

Equity in Athletics, Inc. v. Department of Education, No. 10-1259 (2011, 4th Cir.).

Editorial. (2010, January 15). Title IX four years later wearing thin. The Breeze. Retrieved from http://www.breezejmu.org/article_e56e45e5-a719-502e-a543-2ad932e9dcd8.html

Fagan, K., \& Cyphers, L. (2012, April 30). Five myths about Title IX. ESPN.com. Retrieved from http://espn.go.com/espnw/title-ix/7729603/five-myths-title-ix

Fairbank, D. (2011, August 22). JMU football set to debut expanded stadium. The Daily Press. Retrieved from http: articles.dailypress.com.

Glover, W.H. (2011, March 25). Gender participation issues related to sports - Title IX of the Education Amendments of 1972. Lexis Nexis Practice Area Hub: Gender Participation Issues Related to Sports. Retrieved from http://lexisnexis.com

Goldenbach, A. (2006, November 3). "Title IX protest at Education Department Highlights JMU's cuts." Washington Post. Retrieved from http://www.washingtonpost.com/wpdyn/ content/article/2006/11/02/AR2006110201530.html.

Hoffman, K. (2012, June 23). Title IX creates opportunities while taking many away. Coach and Athletic Director. Retrieved from http://www.coachad.com/pages/HuddleUp-Kevin-Hoffman-Title-IX-Creates-Opportunities-While-Taking-Many-Away.php

Hogshead-Makar, N., \& Zimbalist, A. (2007). Equal play: Title IX and social change. Philadelphia, PA: Temple University Press.

Hogshead-Makar, N. (2012). Hurricane warning flag for Olympic sports: Compliance practices in Biediger v. Quinnipiac University signal a risk to women's and men's Olympic sports. Boston College Law Review. Boston College. Law School, 54(2), 465-476.

Irick, E. (2011, October). NCAA sports sponsorship and participation report 2010- 2011. Indianapolis, IN: National Collegiate Athletic Association.

James Madison University athletic complex and stadium (2012). Retrieved from http:// www.jmusports.com

James Madison University intercollegiate athletics programs for the year ended June 30, 2005. A report prepared by the Auditor of Public Accounts, Commonwealth of Virginia.

James Madison University intercollegiate athletics programs for the year ended June 30, 2006. A report prepared by the Auditor of Public Accounts, Commonwealth of Virginia.

James Madison University intercollegiate athletics programs for the year ended June 30, 2007. A report prepared by the Auditor of Public Accounts, Commonwealth of Virginia.

James Madison University intercollegiate athletics programs for the year ended June 30, 2008. A report prepared by the Auditor of Public Accounts, Commonwealth of Virginia.

James Madison University intercollegiate athletics programs for the year ended June 30, 2009. A report prepared by the Auditor of Public Accounts, Commonwealth of Virginia.

James Madison University intercollegiate athletics programs for the year ended June 30, 2010. A report prepared by the Auditor of Public Accounts, Commonwealth of Virginia.

James Madison University intercollegiate athletics programs for the year ended June 30, 2011. A report prepared by the Auditor of Public Accounts, Commonwealth of Virginia.

James Madison University Equity in Athletics Disclosure Act Report, 2006-2007.” Retrieved from http://ope.ed.gov/athletics/InstDetail.asp. 
James Madison University Equity in Athletics Disclosure Act Report, 2010-2011.” Retrieved from http://ope.edu.gov/athletics/InstDetail.asp.

JMU athletics leading the way since 2000-2001." (2011, August 17). Retrieved from http:// www.jmusports.com

JMU enacts proportionality plan to comply with Title IX." James Madison University Staff. (2006, September 29). Retrieved from http://www.jmu.edu/jmuweb/general/news/ general7490.shtml.

JMU Dukes: Capital projects". (2007, June 17). Retrieved from http://www.jmusports.com

JMU staff directory." (2012-2013). Retrieved from http://www.jmusports.com.

JMU student handbook". (2012). Student Duke Club. Retrieved from http://www.jmu.edu/ judicial/handbook/StudentLifeSDC.html

JMU Title IX statement." (2007). Retrieved from http://www.jmu.edu/jmuweb/general/ news2/general8145.shtml

JMU to break ground for athletic performance center June". (2003, June 3). Retrieved from http://www.jmu.edu/jmuweb/general/news2/general_20036311178.shtml

Judge, J., \& O'Brien, T. (2012). Equity and Title IX in intercollegiate athletics. Indianapolis, IN: National Collegiate Athletic Association.

Keep all 28 sports teams, JMU administration recommends." James Madison University press release. (2001, Feb. 22). Retrieved from http://www.jmu.edu/mediarel/PR-thisrelease. asp?AutoID $=465$

Kerr, C. (1991). The new race to be Harvard or Berkeley or Stanford. Change, 23(30), 8-15. doi:10.1080/00091383.1991.9937687

King, C. (2006, November). James Madison University administrative \& finance newsletter. Retrieved from http://www.jmu.edu/adminfinance/news/nov2006.shtml.

King, C. (2012). Annual report 2011-2012: For the year 7/1/2011-6/30/2012. Harrisonburg, VA: James Madison University.

Langton, V. (2009). Stop the bleeding: Title IX and the disappearance of men's collegiate athletic teams. Vanderbilt Journal of Entertainment and Technology Law, 12(1), 183-204.

Lemke, T. (2006, November 3). Group protests Title IX, The Washington Times, pp. C01.

Lipka, S. (2006). In a new twist on 'equal opportunity', a university cuts elsewhere, equity advocates fear. The Chronicle of Higher Education.

Lopiano, D. (2006, October 6). "Public comment: James Madison University's decision to cut women's sports.” Retrieved from http://www.womenssportsfoundation.org.

Lopiano, D. (2006, November). "James Madison University and Title IX: Myths and facts." Retrieved from http://www.womenssportsfoundation.org/cgi-bin/iowa/issues/disc/ article.html? record=1158.

Lopiano, D.A. (2011, April 26). The proper use and abuse of roster management. Sport Management Resources. Retrieved from http://www.sportmangementresources.com/ $\operatorname{print} / 240$

Lukas, C. (2012, June 22). Title IX's dark legacy. U.S. News \& World Report. Retrieved from http://www.usnews.com/opinion/articles/2012/06/22/title-ixs-dark-legacy

McAndrews, P. J. (2012). Keeping score: How universities can comply with Title IX without eliminating men's collegiate athletic programs. Brigham Young University Education and Law Journal, 111-140.

MacDonald, M. (2012, April 23). Archery's long list of achievements grows after big wins at Eastern Regional Intercollegiate Championships in Williamsport this weekend. The Breeze. Retrieved from http://www.breezejmu.org/sports/article_88c75ab4-8ce0-11e1a98c-001a4bcf6878.html?mode=print

McCarthy Communications. "JMU's reform Title IX rally in front of the U.S. Department of Education." (2006). Retrieved from http://www.mccarthycommunications.net/photos/.

National Collegiate Athletic Association. (2012). NCAA accumulated attendance report: Average football attendance - Football Championship Series. Retrieved from http:// www.ncaa.org 
National Women's Law Center. (2011, September 7). Brief for Amici Curiae National Women's Law Center, et al. in support of plaintiffs-appellees and urging affirmance. Beidiger v. Quinnipiac University. Case: 10-3302

National Women's Law Center. (2012, January 30). Debunking the myths about Title IX and athletics. Washington, DC: National Women's Law Center. Retrieved from http:// www.nwlc.org/resource/debunking-myths-about-title-ix-and-athletics

Pemberton, C. (2012). More of the same - enough already! Marquette Sports Law Review, 22(2), 596-609.

Pennington, B. (2006, October 7). "At James Madison, Title IX is satisfied but students are not." New York Times. Retrieved from http://www.nytimes.com/2006/10/07/sports/ othersports/07madison.html?n=Top/Reference/Times\%20Topics/People/P/Pennington, \%20Bill.

Pennington, B. (2007). "Fair play? James Madison University's decision to eliminate 10 sports teams-mostly men's - to comply with federal "gender equity" law is the latest chapter in the debate over the fairness of Title IX." New York Times Upfront. Retrieved from http://findarticles.com/p/articles/mi_m0BUE/is_8_139/ai_n17216097/pg_3.

Redden, E. (2006, October 3). "Gender equity or finances?" Inside Higher Education. Retrieved from http://www.insidehighered.com/layout/set/print/news/2006/10/03/jmu.

Reynolds, G. (2003, July 11). Further clarification of intercollegiate athletics policy guidance regarding Title IX compliance. Washington, DC: U.S. Department of Education Office for Civil Rights. Retrieved from http://www2.ed.gov/print/about/offices/list/ ocr/title9guidanceFinal.html

Ridpath, D., Yiamouyiannis, A., Lawrence, H., \& Galles, K. (2008). Changing sides: The failure of the wrestling community's challenges to Title IX and new strategies for saving NCAA sport teams. Journal of Intercollegiate Sport, 1(2), 255-283.

Sack, A.L., \& Staurowsky, E.J. (1997). College athletes for hire: The evolution and legacy of the NCAA amateur myth. Westport, CT: Praeger Press.

Samuels, J., \& Galles, K. (2003). In defense of Title IX: Why current policies are required to ensure equality of opportunity. Marquette Sports Law Review, 14(1), 10-47.

Sander, L. (2011, March 8). James Madison U.'s elimination of 10 sports teams was legal, appeals court affirms. The Chronice of Higher Education. Retrieved from http://www. chronicle.com

Schlabach, M. (2012, May 18). LSU faces smooth road to title game. ESPN.com.

Sperber, M. (2000). Beer and circus: How big-time college sports is crippling undergraduate education. New York: Henry Holt \& Company.

Staurowsky, E. J. (2006, December). James Madison University's decision to cut athletic teams: A farce or a tragedy? Sport Litigation Alert, 3 (21).

Staurowsky, E.J. (2007, Summer). Searching for James Madison in JMU's 2006 decision to cut sports in the name of Title IX. Harvard Journal of Gender and Law 31 (2). Retrieved at http://www.law.harvard.edu/students/orgs/jlg/next/tocs.php\#312.

Staurowsky, E.J. (2011). Title IX literacy: What every citizen should know about Title IX, gender equity, and college sport. For inclusion. In B. Lampman (Ed.), Learning culture through sport: Exploring the role of sport in society (2nd ed., pp. 107-123). Lanham, MD: Rowman \& Littlefield.

Steinbach, P. (2000, October 1). Roster management takes pain out of Title IX compliance. Athletic Business. Retrieved from http://fitness- management.com/articles/article. aspx ?articleid $=55 \&$ zoneid $=3$

Stubbs, R. (2012, September 15). West Virginia football vs. James Madison: Mountaineers too much for Dukes. The Washington Post. Retrieved from http://www.washingtonpost. $\mathrm{com} /$ sports/west-virginia-football-vs-james- madison-mountaineers-too-much-fordukes/2012/09/15/77add7fa-ff89-11e1-b153-218509a954e1_story.html

Thomas, K. (2011, April 25). College teams, relying on deception, undermine gender equity. New York Times. Retrieved from http://www.nytimes.com. 
Title IX statement.” James Madison University Staff. (2007, February 8). Retrieved from http://www.jmu.edu/jmuweb/general/news/general8145.shtml.

Toporek, B. (2012, January 10). U. S. Supreme Court declines to hear appeal of Title IX case. Education Week. Retrieved from http://blogs.edweek.org/edweek/schooled_in_ sports/2012/01/us_supreme_court_declines_to_hear_appeal_of_title_ix_case.html

U.S. Department of Health, Education, \& Welfare (1975). Title IX statute. Code of Federal Regulations 34, Part 86.

U.S. Department of Health. Education \& Welfare (1979, December 11). A policy interpretation: Title IX and intercollegiate athletics. Federal Register 44, (239), n.p. Retrieved from http://www2.ed.gov/print/about/offices/list/ocr/docs/t9interp.html

Walton, T.A., \& Helstein, M.T. (2008). Triumph of backlash: Wrestling community and the "problem" of Title IX. Sociology of Sport Journal, 25, 369-386.

Ware, S. (2011). Game, set, and match: Billie Jean King and the revolution in women's sports. Chapel Hill, NC: University of North Carolina Press.

Weaver, A. (2010). Reevaluating prestige: The influence of history on the decision to reclassify to Division I: A case study. Journal of Issues in Intercollegiate Athletics., 3, 131-153 Retrieved from http://csri-jiia.org/documents/puclications/research_articles/2010/ JIIA_2010_3_8_131_153_Reevaluating\%20Prestige.pdf.

Weiner, J. (2009, October). College sports 101: A primer on money, athletics, and higher education in the $21^{\text {st }}$ century. Washington, DC: Knight Commission on Intercollegiate Athletics. 